\title{
"Affordable housing for internally displaced persons: The priorities for investment and development in Ukraine"
}

\author{
Lyudmyla Alekseyenko iD https://orcid.org/0000-0003-4840-0188 \\ R https://publons.com/researcher/2130864// \\ Oksana Tulai iD https://orcid.org/0000-0002-5588-7046 \\ R https://publons.com/researcher/2118085/oksana-tulai/ \\ AUTHORS \\ Yuriy Petrushenko iD https://orcid.org/0000-0001-9902-7577 \\ R http://www.researcherid.com/rid/C-1072-2018 \\ Andriy Kuznietsov iD https://orcid.org/0000-0003-0401-3901 \\ R https://publons.com/researcher/1942486/a-kuznietsov/ \\ Julia Derkash iD https://orcid.org/0000-0002-5195-1821 \\ R https://publons.com/researcher/1942498/julia-derkach/
}

Lyudmyla Alekseyenko, Oksana Tulai, Yuriy Petrushenko, Andriy Kuznietsov and Julia Derkash (2021). Affordable housing for internally displaced persons:

ARTICLE INFO The priorities for investment and development in Ukraine. Investment Management and Financial Innovations, 18(1), 101-113. doi:10.21511/imfi.18(1).2021.09

\begin{tabular}{|c|c|c|}
\hline DOI & \multicolumn{2}{|c|}{ http://dx.doi.org/10.21511/imfi.18(1).2021.09 } \\
\hline RELEASED ON & \multicolumn{2}{|l|}{ Tuesday, 02 February 2021} \\
\hline RECEIVED ON & \multicolumn{2}{|l|}{ Monday, 05 October 2020} \\
\hline ACCEPTED ON & \multicolumn{2}{|l|}{ Sunday, 24 January 2021} \\
\hline & \multicolumn{2}{|l|}{$(\mathrm{oc}) \mathrm{EYY}_{\mathrm{BY}}$} \\
\hline LICENSE & \multicolumn{2}{|c|}{$\begin{array}{l}\text { This work is licensed under a Creative Commons Attribution } 4.0 \text { International } \\
\text { License }\end{array}$} \\
\hline JOURNAL & \multicolumn{2}{|c|}{ "Investment Management and Financial Innovations" } \\
\hline ISSN PRINT & \multicolumn{2}{|l|}{$1810-4967$} \\
\hline ISSN ONLINE & \multicolumn{2}{|l|}{$1812-9358$} \\
\hline PUBLISHER & \multicolumn{2}{|c|}{ LLC "Consulting Publishing Company "Business Perspectives" } \\
\hline FOUNDER & \multicolumn{2}{|c|}{ LLC “Consulting Publishing Company "Business Perspectives" } \\
\hline & & $\begin{array}{l}= \pm: \\
=\Xi-5\end{array}$ \\
\hline NUMBER OF REFERENCES & NUMBER OF FIGURES & NUMBER OF TABLES \\
\hline 32 & 3 & 4 \\
\hline
\end{tabular}

(C) The author(s) 2021. This publication is an open access article. 


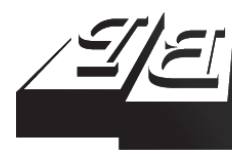

BUSINESS PERSPECTIVES

(2)

LLC "CPC "Business Perspectives" Hryhorii Skovoroda lane, 10, Sumy, 40022, Ukraine www.businessperspectives.org

Received on: $5^{\text {th }}$ of October, 2020 Accepted on: $24^{\text {th }}$ of January, 2021 Published on: $2^{\text {nd }}$ of February, 2021

๑) Lyudmyla Alekseyenko, Oksana Tulai, Yuriy Petrushenko, Andriy Kuznietsov, Julia Derkash, 2021

Lyudmyla Alekseyenko, Doctor of Economics, Professor, Head of the Department of Management and Administration, Ivano-Frankivsk Education and Research Institute of Management, West Ukrainian National University, Ukraine.

Oksana Tulai, Doctor of Economics, Professor, Department of Finance named after S. I Yuriy West Ukrainian National University, Ukraine.

Yuriy Petrushenko, Doctor of Economics, Professor, Head of the Department of International Economic Relations, Sumy State University, Ukraine. (Corresponding author)

Andriy Kuznietsov, Ph.D. in Economics, Senior Lecturer, Department of Management, Odesa National Economics University, Ukraine.

Julia Derkash, Ph.D. in Economics, Senior Lecturer, Department of Banking, Odesa National Economics University, Ukraine.
Lyudmyla Alekseyenko (Ukraine), Oksana Tulai (Ukraine), Yuriy Petrushenko (Ukraine), Andriy Kuznietsov (Ukraine), Julia Derkash (Ukraine)

\section{AFFORDABLE HOUSING FOR INTERNALLY DISPLACED PERSONS: THE PRIORITIES FOR INVESTMENT AND DEVELOPMENT IN UKRAINE}

\begin{abstract}
The institution of home ownership provides for the functioning of affordable housing for low-income people and new groups in need of social protection, including the reintegration of migrants to new places of residence.

The aim of the study is to substantiate the priorities of investments into affordable housing for internally displaced persons promoting their adaptation and social reintegration in the context of administrative-territorial decentralization.

The study is based on use of empirical, economic and statistical methods, which in the process of correlation, regression and canonical analysis showed that many indicators that characterize the housing market are closely correlated with the scale and development level of administrative units in Ukraine. To characterize the state and investment attractiveness of the residential real estate market, a set of indicators was used in the modeling: population, the number of employed, household income, regional domestic product, volume of commissioned housing, construction investments, regional human development index, total housing stock, housing prices in the regions of Ukraine and Kyiv. The most significant parameter that affects the volume of housing construction is the amount of investments into per capita housing construction.
\end{abstract}

The article also discusses the housing market situation, which differs in regions or some cities due to the significant differentiation of their development, which affects the ability to obtain affordable housing. The implementation of regional development programs should determine investment priorities of social protection, particularly the possibility of buy-out schemes through the mechanism of leasing of social housing by internally displaced persons.

\section{Keywords volume of investment in construction, household income, number of employed, housing prices, regional human development index, internally displaced persons}

JEL Classification R21, G17, G23

\section{INTRODUCTION}

Meeting the needs of citizens in social housing is vital for low-income earners and emerging groups such as internally displaced persons. The need to ensure housing availability for different categories of the population requires the search for new forms and methods of attracting different sources of funding for residential real estate. On the one hand, it can be argued that the general investment climate in Ukraine is unfavorable due to economic and political instability, but, on the other hand, as the results of the study showed, Ukraine is favorable for investment because it has reached an acceptable level of effective tax rates (Andrejovska et al., 2020).

Therefore, it is necessary to find instruments to raise funds at different stages of investment projects in residential real estate, taking into account the level of development of administrative-territorial units, which will enable to reduce the deficit of affordable housing and the 
population's need for safe and quality housing. Investing in residential real estate involves investors' money, securities, intellectual property, property rights in residential real estate to generate income or achieve a social effect, including the provision of affordable housing. Investments in residential real estate are long-term, associated with the length of investment cycles and payback periods, which requires minimizing the cost of resources and the formation of guarantee mechanisms to ensure the efficiency of financial investments, including state participation.

The institution of home ownership, formed in the world economy, is the predominant form of real estate use, and the tendency to increase the share of housing owned by citizens has been achieved through relatively easy access to mortgages. In Ukraine, high rates of housing ownership have been achieved in the process of privatization of the state housing stock. The country develops a social housing sector, while new state initiatives, including housing investments under the Affordable Housing Program, local credit programs, and the provision of housing subventions from the budget for internally displaced persons, are at an early stage of implementation.

The military conflict in Eastern Ukraine and the annexation of Crimea have recently resulted in many internally displaced persons in need of public support. According to the Unified Information Database on Internally Displaced Persons, as of the end of December 2019, 1,432,290 migrants from the temporarily occupied territories of Donetsk and Luhansk regions and the Autonomous Republic of Crimea were registered, and as of November 2, $2020-1,458,161$. Simultaneously, the number of migrants is constantly growing. According to a survey conducted by the International Organization for Migration, only $11 \%$ of internally displaced persons in Ukraine now live in their own homes, about $60 \%$ have been renting apartments for more than six years, and $17 \%$ live with relatives or host families.

\section{LITERATURE REVIEW}

Investing ensures the placement of funds for their preservation and growth. Kwenda (2015) defines the relationship between cash flows, investments, and financial constraints. The issues of investments in housing, the setting of housing prices, adjusting the quality of housing, and the impact of restrictive rules on housing supply were considered by Kohlscheen et al. (2020). Jacobsen et al. (2007) recognize that the development of the labor market contributes to the progressive movement of investments into housing and housing stock growth, which restrains the growth of housing prices.

The comparative studies of housing aim to determine its place in the social, economic, and political spheres of different countries, as well as instruments of housing policy and their effectiveness. Ding et al. (2017) analyzed the fundamental imbalances in the housing market. Curto and Fregonara (2019) outlined the basic methodologi$\mathrm{cal}$ principles of real estate pricing. The main practical implication of Lisi (2019) is that the house price dispersion is an inherent phenomenon in the house search and matching process. Wyatt (2018) considers the provision of affordable housing from a land value capture viewpoint, focusing on how the amount of affordable housing is determined between landowners/developers, on the one hand, and local planning authorities, on the other hand. Rosser and Sanders (2017) analyzed the trends and contradictions in the historical retrospect of the residential real estate market.

The term "social housing" is interpreted as houses and flats owned by the local government or by other organizations that do not make a profit and are rented to people who have low incomes (Cambridge Dictionary, 2017). Social housing is a subject of confrontation between different interest groups because, on the one hand, social housing is a basic necessity for a person, and on the other hand - the impossibility of fair distribution of housing in a market economy due to profit motive (Barannik \& Sokovets-Makatukha, 2015). The issues of increased housing affordability were considered in the works of Harelimana (2017), Abelson (2009), Hudz and Sharova (2014). In their works, they considered the issue of increasing the availability of housing. 
Hansson and Lundgren (2019) determine that the term social housing has been characterized as a "floating signifier", i.e., a term with no agreed-upon meaning. Ogden (2020) recognizes that the role of social housing is changing since social housing employees have embraced working from home during the COVID-19 pandemic, as most workers see increased levels of remote working as the future of work in the sector, a new report has revealed. Legal principles of housing ownership determine the level of social security of individuals and require state regulation of housing construction and use.

Theoretical problems of the role of the state in guaranteeing property rights and compliance with construction and land agreements were widely studied by Asaul et al. (2005). Smith et al. (2006) drew attention to the influence of socio-behavioral factors on real estate financing. Binovska et al. (2018) analyzed the process of attracting investments to the housing market and forming a favorable investment climate. Sadoviak (2019) focuses on investments in housing construction by different economic entities.

The dominant problem in the context of administrative-territorial reform is the financial feasibility. Woznyak (2019) argues that in the context of the financial decentralization reform in Ukraine, to support the individual construction of those segments of the population, which are poorly provided by adequate housing, it is necessary to intensify housing construction through the implementation of local housing programs. However, there is an alternative opinion that subsidizing housing ownership for certain categories of the population does not meet the goals of economic efficiency and social justice (Fedoriv \& Lomonosova, 2019). Diachenko (2018) rightly notes that the provision of housing to internally displaced persons is a key mechanism for their adaptation and social integration.

Many studies were devoted to the issue of mortgage investment, as its intensification has been facilitated by the banking sector's liberalization and the development of mortgage instruments. Bhagat (2017) identified the theoretical postulates of mortgage state policy and the impact of the financial crisis. Torluccio and Dorakh (2011) offered an approach that enables determining more effective ways of solving the housing problem through a comprehensive evaluation of housing needs and opportunities for the banking system to engage in lending. Mitra and Walczak (2012) determine the influence of microeconomic factors in the choice of modern mortgage instruments. Tajani and Morano (2018) proposed an innovative methodology for assessing mortgage lending value. The development of the mortgage market will promote the interest of financial institutions in investing assets in long-term projects and mortgage lending programs, including soft loans for up to 20 years with an interest rate of $3 \%$ per annum for the purchasing of housing by internally displaced persons.

\section{AIMS}

The aim of the study is to substantiate the priorities of investments into affordable housing for internally displaced persons promoting their adaptation and social reintegration in the context of administrative-territorial decentralization.

\section{METHODS}

The study is based on the data of the State Statistics Service of Ukraine and the calculations of the authors based on the use of a set of empirical and economic-statistical methods of scientific analysis. The monographic method, methods of analysis and synthesis were used in the study of affordable housing in the world practice and in Ukraine and the classification of affordable housing and sources of investment to address the housing needs of internally displaced persons and their adaptation and social reintegration.

Economic and statistical methods were used to identify and quantify the relationships between individual phenomena and processes that reflect the state and sources of funding in the housing segment and a set of criteria that characterize the level of supply on the housing market.

Pearson's methods of correlation analysis and pairwise correlation coefficients were used to establish the level of the relationship between the volume of housing stock and the population, as 
well as the number of employed persons; between the volumes of housing stock and income per capita, domestic regional product per capita, the volume of investments in housing construction, housing prices; between housing prices and the human development index in the region.

Methods of multiple linear regression analysis were used to build a three-dimensional graph of household income dependence, the volume of investment in housing construction per capita, and the volume of housing commissioned per capita.

Methods of scientific abstraction and canonical correlations were used to determine the density of relationship between the indicators that reveal the state and sources of funding for housing, and a set of criteria that in some way characterize the supply on the housing market, taking into account the level of administrative-territorial units.

\section{RESULTS}

The provision of funding and lending to the social housing sector is one of the country's main challenges, as in the conditions of a hybrid war, internally displaced persons require an acceptable model of social housing. It should be noted that Azerbaijan, Georgia, Iraq, Nigeria, Syria, Sudan, and the countries formed after the breakup of Yugoslavia and others, faced this problem of reintegration.

For the reintegration of displaced persons, the United Nations Organization in 1998 adopted the Guiding Principles on Internal Displacement. According to the document, internally displaced persons are persons or groups of persons who have been forced or obliged to flee or to leave their homes or places of habitual residence, in particular as a result of or to avoid the effects of armed conflict, situations of generalized violence, violations of human rights or natural or human-made disasters, and who have not crossed an internationally recognized state border.

These Guiding Principles are aimed at meeting the special needs of internally displaced persons, so the country must take into account the rights and guarantees necessary to protect persons from involuntary relocation and provide them with protection and assistance during relocation, resettlement, and reintegration. Accordingly, the country's state authorities are obliged to assist this category of the population, including the guarantee of appropriate living conditions.

According to Cazabat and Tucci (2019), "Internal displacement limits people's ability to contribute to the economy and generates specific needs that must be paid for by IDPs, their hosts, their government or other aid providers" (p. 5). Countries define the concept of "social housing" differently depending on the designation of housing, housing stock, or apartment building. However, social housing is an integral part of the housing and is designed to meet the housing needs of those who cannot afford to buy or rent their own housing.

Affordable housing includes housing and civil facilities designed to provide low-income people and new groups, such as internally displaced persons, with adequate housing, which requires investments and appropriate administrative and legal support. As an object of investment, residential real estate requires long-term and large-scale investments, development of approaches to the formation of rational investment support of the housing construction projects at different stages of their implementation, and the formation of guarantee mechanisms to ensure the return on investment. Different economic entities and individuals can carry out investments in affordable housing through construction financing funds, the issuance of special-purpose bonds, mutual investment institutions, and real estate funds.

In Ukraine, following the world practice of migrants reintegration, the procedure for forming housing funds for temporary residence of internally displaced persons who do not have or have lost housing is legally defined (Cabinet of Ministers of Ukraine, 2019). This model of affordable housing provides, first of all, for the creation of a housing stock of temporary housing for internally displaced persons through the construction and purchasing of new housing, reconstruction of residential buildings and dormitories, conversion of non-residential premises into housing, transfer of housing to communal ownership, financing of accommodation in sanatoriums and health re- 
sorts, other institutions of social protection, rent payment, etc. Second, state support through the Affordable Housing Program is 50\% of the cost of housing construction (purchase) for internally displaced persons, which are included in the Unified Information Database on Internally Displaced Persons. In 2017, UAH 30 million was allocated to finance the program of construction of affordable housing for internally displaced persons; in 2018 UAH 100 million, and in 2020 - UAH 100 million was allocated by the state budget. Simultaneously, in 2018, only 273 internally displaced persons benefited from this program, which is meager compared to the real needs (State Fund for Support of Youth Housing Construction, 2020).

The shortage of affordable housing leads to an increase in the need for social housing. Effective integration of internally displaced persons into local communities is an extremely difficult task due to the need for significant investments and financial resources, primarily to cover the cost of living and paying for housing and communal services. Therefore, more efforts should be made to stimulate the growth of housing construction by introducing effective investment mechanisms to reduce the cost of housing for this category of the population. Construction companies can attract investments into housing construction through options and sales of unfinished buildings to increase the volume of affordable housing and reduce costs.

The development of administrative-territorial units and the housing stock also affect opportunities for internally displaced persons, as due to the lack of affordable housing, other rights of these persons become less affordable. Before further research, it should be noted that the time range of 2011-2015 was chosen for analysis for two reasons: first, due to the availability of detailed consistent data by region; second, due to the influence of the factor of hostilities in eastern Ukraine and a significant reduction in the influence of the Russian Federation on the economy of Ukraine (2014 can be considered a turning point). For the practical implementation of the study, the software package of statistical analysis "Statistica" is used, which provides an opportunity to process large amounts of information.

The initial general analysis was carried out by building a correlation matrix for a set of statisti- cal indicators based on which a decision was made for further analysis. The following statistics were taken into account: population (N); number of the employed (B); household income (M); regional domestic product (R); the volume of the commissioned housing (A); the volume of investments in construction (C); regional human development index (I); the volume of housing stock (S); housing prices $(\mathbf{P})$ in the regions of Ukraine and Kyiv for five years. The built matrix data were used for correlation, regression, and canonical analysis.

The formation of the information and analytical matrix occurs for a specific period, namely for 2015. Table 1 shows a matrix of paired Pearson correlation coefficients, which illustrate the presence or absence of a stochastic linear relationship between the studied variables. Table 1 reflects a very close correlation between the population and its employment, demonstrating the typical situation throughout Ukraine.

There is a high correlation between the volume of housing stock and the population and the number of the employed. One can observe a slightly lower but still significant correlation between the volume of housing stock and household per capita income, $\mathbf{R}$ per capita, the volume of investment in housing construction, housing prices. An indicative fact is a correlation between housing prices and the human development index in the region. This can be explained as follows: the higher the level of development of the region, the better the infrastructure and more comfortable living conditions, which, leads to higher housing prices.

The analysis showed that many indicators that characterize the housing market in Ukraine are closely correlated with the scale and level of development of administrative-territorial units. It is difficult to compare regions with a larger population and higher level of development (for example, Kyiv, Kyiv region with Chernihiv region) and higher incomes with other regions. Therefore, one believes that it is advisable to analyze the relative market indicators that do not depend on these indicators.

Real estate is a profitable investment, so the volume of new per capita housing will not be significantly determined by the amount of income received in Ukraine. Therefore, this situation is 
Table 1. Matrix of paired correlation coefficients between indicators that comprehensively characterize the residential real estate market of Ukraine in 2015

\begin{tabular}{|c|c|c|c|c|c|c|c|c|c|}
\hline & & & & & & & & \multicolumn{2}{|c|}{ Source: Own processing. } \\
\hline & $\mathbf{N}$ & B & $\begin{array}{c}M \text { (per } \\
1 \text { person) }\end{array}$ & $\begin{array}{c}R \text { (per } \\
1 \text { person) }\end{array}$ & A & C & 1 & $S$ & $\mathbf{P}$ \\
\hline $\mathbf{N}$ & 1.000 & $0.997 * * *$ & $0.719 * * *$ & $0.588^{* *}$ & -0.029 & 0.299 & 0.374 & $0.952 * * *$ & $0.656^{* * *}$ \\
\hline B & $0.997^{* * *}$ & 1.000 & $0.731 * * *$ & $0.600^{* *}$ & -0.053 & 0.267 & 0.370 & $0.951 * * *$ & $0.622 * *$ \\
\hline $\begin{array}{c}M \text { (per } \\
1 \text { person) }\end{array}$ & $0.719 * * *$ & $0.731^{* * *}$ & 1.000 & $0.881^{* * *}$ & -0.140 & 0.140 & -0.008 & $0.750 * * *$ & 0.144 \\
\hline $\begin{array}{c}\mathrm{R} \text { (per } \\
1 \text { person) }\end{array}$ & $0.588^{* *}$ & $0.600^{* *}$ & $0.881^{* * *}$ & 1.000 & -0.018 & 0.202 & 0.019 & $0.666^{* * *}$ & 0.076 \\
\hline A & -0.029 & -0.053 & -0.140 & -0.018 & 1.000 & $0.887 * * *$ & 0.264 & 0.158 & 0.115 \\
\hline C & 0.299 & 0.267 & 0.140 & 0.202 & $0.887^{* * *}$ & 1.000 & 0.308 & $0.466^{*}$ & 0.275 \\
\hline 1 & 0.374 & 0.370 & -0.008 & 0.019 & 0.264 & 0.308 & 1.000 & 0.315 & $0.480^{*}$ \\
\hline S & $0.952 * * *$ & $0.951^{* * *}$ & $0.750^{* * *}$ & $0.666^{* * *}$ & 0.158 & $0.466^{*}$ & 0.315 & 1.000 & $0.533^{*}$ \\
\hline $\mathbf{P}$ & $0.656 * * *$ & $0.622^{* *}$ & 0.144 & 0.076 & 0.115 & 0.275 & $0.480^{*}$ & $0.533^{* *}$ & 1.000 \\
\hline
\end{tabular}

Note: The correlation coefficient is significant for: ${ }^{*} \mathrm{p}<0.05 ;{ }^{* *} p<0.01 ; * * p<0.001$

observed mainly in areas characterized by significant external labor migration. This is to some extent confirmed by Figure 1.

Figure 1 illustrates high rates of $A$ per capita in The next stage of the study of the peculiarities of the 2014 in the western regions of Ukraine (Volyn, residential real estate market in Ukraine is to conZakarpattia, Ivano-Frankivsk, Ternopil, etc.). duct a regression analysis. As a result of this analysis,

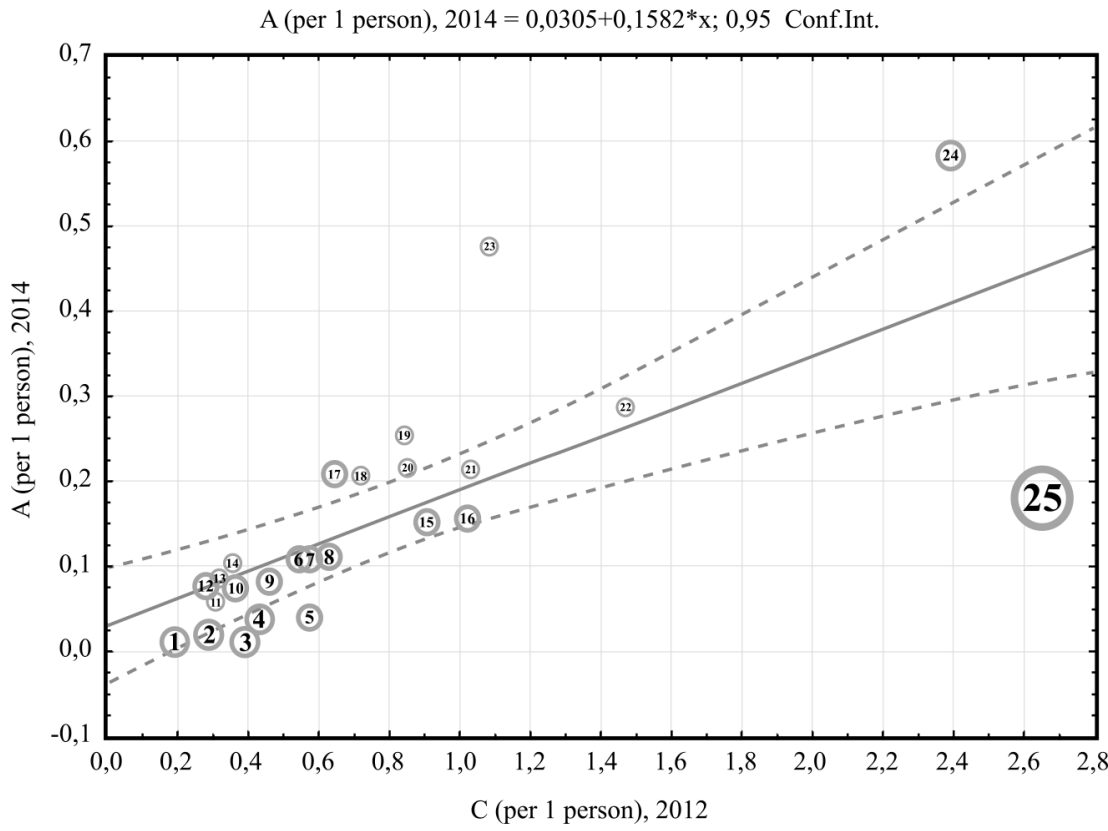

Note: 1 - Luhansk region; 2 - Dnipro region; 3 - Donetsk region; 4 - Zaporizhzhia region; 5 - Kharkiv region; 6 - Sumy region; 7 - Chernihiv region; 8 - Vinnytsia region; 9 - Poltava region; 10 - Zhytomyr region; 11 - Kirovohrad region; 12 - Mykolaiv region; 13 - Cherkasy region; 14 - Kherson region; 15 - Lviv region; 16 - Odesa region; 17 - Khmelnytskyi region; 18 - Rivne region; 19 - Zakarpattia region; 20 - Volyn region; 21 - Ternopil region; 22 - Chernivtsi region; 23 - Ivano-Frankivsk region; 24 - Kyiv region; 25 - Kyiv.

Figure 1. The dependence of the new housing supply on the volume of investment and income per capita (the size of bubbles reflects the amount of income) 
Table 2. The results of multiple linear regression analysis *

\begin{tabular}{l}
$\begin{array}{l}\text { The results of regression analysis for the dependent variable: } \mathrm{A} \\
\text { R } \\
\mathrm{R}^{2}=0,805, \mathrm{~F}(2,19)=45,3\end{array}$ \\
\hline
\end{tabular}

Note: * Regressor - the amount of housing commissioned in 2014, per capita, regressors - the amount of investments in housing construction per capita in 2012, household income per capita in 2012.

several significant regression models of the dependence of the volume of commissioned housing per capita in 2014 and the volume of investments and incomes of the population in 2011-2013 were obtained (see Table 2).

This period (2-year time lag) was chosen because the results of investment in housing construction (housing built, commissioned) will not be observed immediately. The building needs to be designed, constructed, equipped with infrastructure, communications, repairs, etc. That is, objectively, specific statistically documented investment results take time. Besides, if the average prices used for construction (an average between new buildings and secondary housing) are taken into account, it is clear that the equilibrium price will not change immediately.

In this study, it is believed that it is necessary to dwell in more detail on the price aspect of the initial data because it is obvious that the commissioned housing is usually a new building. However, their prices have a direct impact on secondary housing. Of course, the drawback of this approach may be that the situation on this market differs in regions or some cities due to significant differentiation of development: in depressed areas, prices for new buildings may not significantly impact housing prices in the secondary market. However, the revealed close correlation enables us to consider the assumption described above to be true.

As can be seen from Table 2 and Figure 1, the volume of new housing commissioned in 2014 is due to the volume of investments made two years ago and the amount of income of the population. In analytical form, this regression model is as follows (1):

$$
\begin{aligned}
& A(\text { per } 1 \text { person }) \text { in } 2014=0.278+ \\
& +0.233 \cdot C(\text { per } 1 \text { person }) \text { in } 2012- \\
& -0.000013 \cdot M(\text { per } 1 \text { person }) \text { in } 2012 .
\end{aligned}
$$

A three-dimensional graph of income dependence reflects the results of this model, $\mathbf{C}$ per one person and $\mathbf{A}$ per one person, approximated by a linear surface (plane) (Figure 2). This graph on axis $\mathrm{X}$ shows the income of the population, on axis $\mathrm{Y}$ - the amount of investments in housing construction per one person, on axis $\mathrm{Z}$ - the volume of housing commissioned per one person.

The linear plane (surface) is divided by shades (repeated signatures of axis Z), where the volume of housing commissioned per person is marked by shades ranging from light to darker ones. Negative values indicate a decrease in volume.

In the previous regression model, to simplify its adequacy verification and further interpretation, the housing price factor was not included, which is a logical indicator and a basic factor in a situation on the residential real estate market. Therefore, the next step is to include in the model the price of housing as an independent variable, along with those already introduced household per capita income and investments in housing construction per capita. In that way, the model obtained three independent variables that affect the dependent (studied) variable the volume of commissioned housing.

Further inclusion of the price factor in this model did not affect the overall significance of the model. As mentioned above, this factor is the average between the price of new buildings and the price on the secondary housing market. The new model's adequacy is confirmed by a high coefficient of determination $\left(R^{2}=0.846\right)$, in particular, the adjusted one (adj. $\left.R^{2}=0.823\right)$, Fisher's coefficient $(F$ $=36.6, p<0.00001)$ with a significance of $0,05 \%$ for intercept and all coefficients of the regression, which are given in Table 3. 


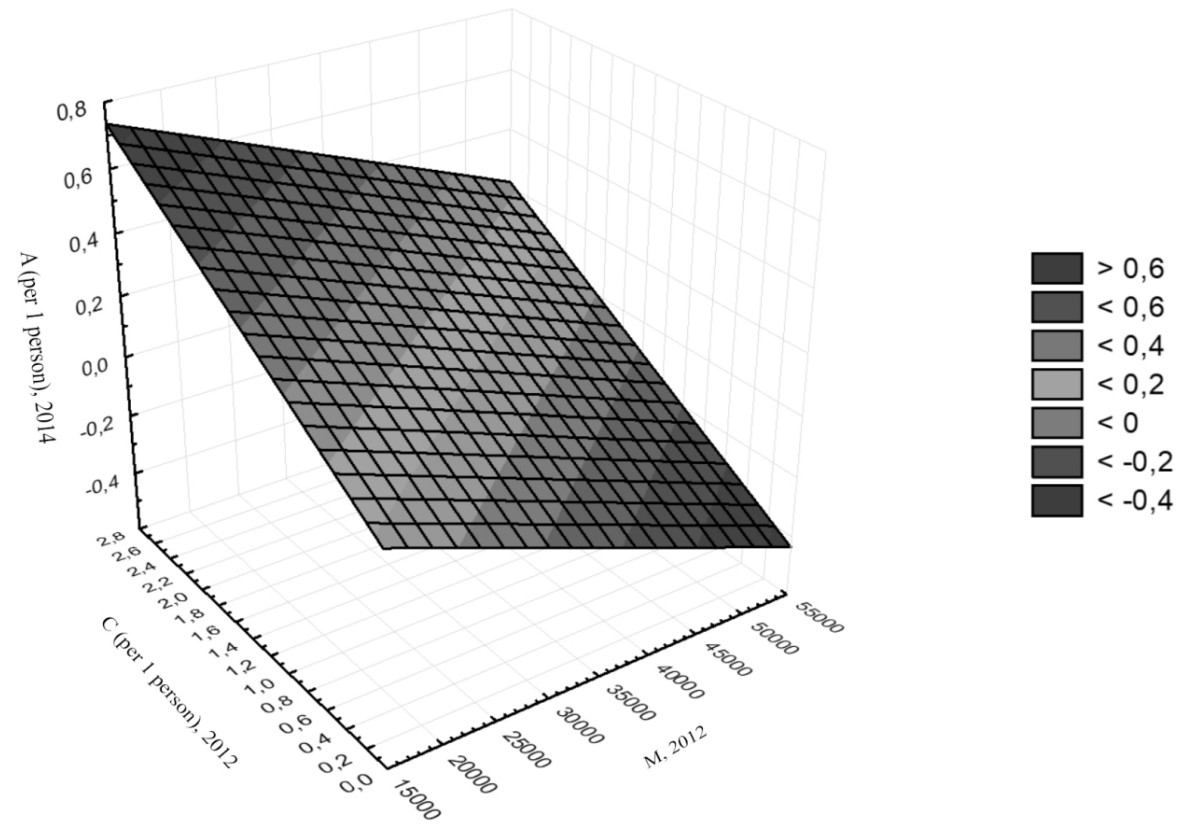

Figure 2. Three-dimensional graph built on the results of the regression model shown in Table 2

Since a set of indicators was used in the modeling for the analysis, characteristics of the state, and financial provision of the residential real estate market, it is expedient to conduct a canonical analysis. Its goal is to check the relationship between two sets of variables, one of which conditionally characterizes certain sources of funding for the industry (M per 1 person, $\mathrm{R}$ per 1 person, $\mathrm{C}$ per 1 person, $\mathrm{P})$, and the other - the supply of housing (A per 1 person, $S$ per 1 person) with a time lag of two years. The results of the analysis indicate a strong canonical correlation between the sets of indicators in 2011 and 2013 (Rc $=0.961, \chi 2(8)=28.9, p=0.00003), 2012$ and 2014 $\left(\mathrm{Rc}=0.961, \chi^{2}(8)=28.9, \mathrm{p}=0.00003\right), 2013$ and $2015(\mathrm{Rc}=0.992, \chi 2(8)=43.9, p=0.00001)$. The scatter diagram of canonical correlations clearly illustrates the relationship between the two sets of indicators, close to linear (Figure 3).
As a result of the analysis of the interdependence of financial indicators in 2012 and indicators of new and secondary housing in 2014, two canonical roots (two variables) were identified. However, according to the criterion $\chi 2$, significant for the level of $p<0.01$, only the first root was identified. When it is removed, the second root becomes insignificant $(\chi 2=0.99, p=0.80)$. Therefore, only the first canonical root was used to further interpret the analysis results.

According to the data of Table 4, in the left set of indicators of financial provision for housing construction, the volume of investments in new housing has the greatest weight for the first canonical root, while the volume of income of the population per one person has a little less weight.

Table 3. The results of multiple linear regression analysis*

\begin{tabular}{l}
$\begin{array}{l}\text { The results of regression analysis for the dependent variable: A } \\
R^{2}=0.846, F(2,19)=36.6\end{array}$ \\
\hline
\end{tabular}

Note: * Regressor - the amount of housing commissioned in 2014, per capita, regressors - the amount of investments in housing construction per capita in 2012, household income per capita in 2012, prices for residential real estate in 2012. 


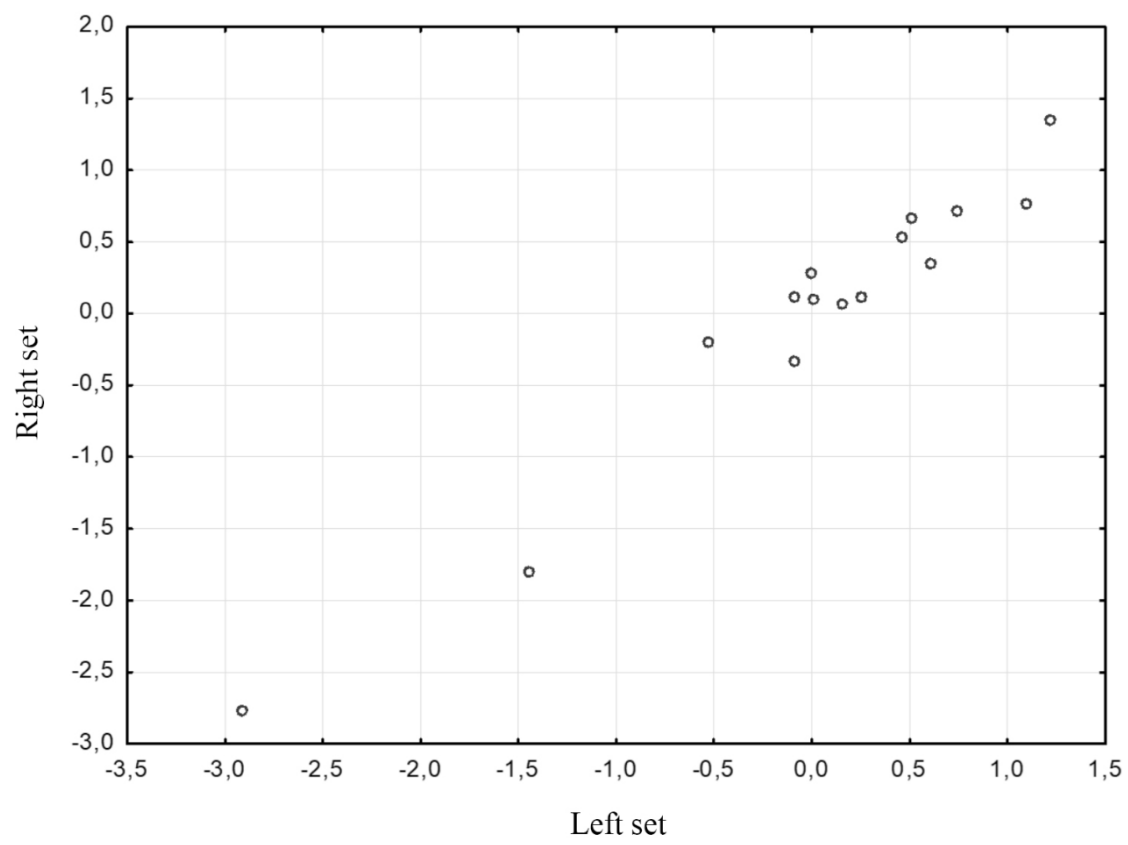

Figure 3. Scatter diagram of canonical correlations for the first canonical root

For the right set of indicators of the volume of new housing and housing in general, the greatest weight is inherent in the variable of housing commissioning volumes. The values of canonical factors loads (see Table 4), which are correlations between the variables from the sets and the corresponding canonical variables, also illustrate the important role of the variables mentioned above in the corresponding sets.

There is a strong relationship between the indicators that reveal the state and sources of funding for the housing industry and a set of criteria that in some way characterize the supply on the housing market. The key role is played by the indicator of investment in housing construction.

\section{DISCUSSION}

It is advisable to pay attention to the need for sound approaches to investing in the social housing sector. The results of calculations show that the significant parameters that affect the volume of commissioned housing include: the amount of investments in housing construction per capita; per capita income; actual housing prices.

This result confirms the observat ion that the amount of investments in housin g construction per person requires applying the interaction model concerning the purchasing of social housing through market mechanisms. The Ministry of Communities and Territories Development of

Table 4. Canonical weights and loads of variables of the first canonical root

\begin{tabular}{|c|c|c|c|c|c|}
\hline \multicolumn{3}{|c|}{ Left set } & \multicolumn{3}{|c|}{ Right set } \\
\hline Variables & $\begin{array}{c}\text { Canonical } \\
\text { weight }\end{array}$ & $\begin{array}{c}\text { Canonical } \\
\text { loads }\end{array}$ & Variables & $\begin{array}{c}\text { Canonical } \\
\text { weight }\end{array}$ & $\begin{array}{c}\text { Canonical } \\
\text { loads }\end{array}$ \\
\hline M (per 1 person) in 2012 & 0.479 & 0.272 & A (per 1 person) in 2012 & -0.875 & -0.985 \\
\hline R (per 1 person) in 2012 & -0.463 & 0.016 & S (per 1 person) in 2012 & -0.203 & 0.677 \\
\hline C (per 1 person) in 2012 & -0.831 & -0.903 & - & - & - \\
\hline$P$ in 2012 & 0.405 & 0.313 & - & - & - \\
\hline
\end{tabular}


Ukraine and the State Fund for the Promotion of Youth Housing Construction are the administrators of state funds allocated to provide soft loans to internally displaced persons. The Ministry of Reintegration of the Temporarily Occupied Territories of Ukraine regulates those interested in obtaining a soft loan to purchase housing for up to 20 years with an interest rate of $3 \%$ per annum. However, certain limitations make it difficult to obtain a loan, including the consistency of interaction between statutory institutions and the borrower's retirement age. In this context, the use of housing leasing as a new financial investment tool in the residential real estate market, which combines the benefits of housing lending and rental housing, will significantly expand the range of internally displaced persons for whom comfortable housing can become affordable.

In the context of administrative-territorial reform, state programs for the acquisition of housing for internally displaced persons will work more effectively if there is a consolidated comprehensive audit of the housing stock; socio-demographic data on those households whose cost structure includes the cost of buying real estate; data on socio-economic characteristics of the population, data on housing overcrowding (Fedoriv \& Lomonosova,
2019). The formation of social rental agencies will promote the development of alternative ownership of affordable housing and regulation of the social and legal environment, which is relevant for internally displaced persons to conclude collective agreements on rent and eviction procedures.

It is necessary to improve the pricing system in the social housing segment. A tool to curb speculative growth in residential real estate prices is a tax on real estate other than land plots (Alekseyenko et al., 2017). This tax contributes to the replenishment of local budgets, enables us to mitigate significant levels of incomes differentiation and their accumulation in the hands of individuals; encourages property owners to use real estate more efficiently; prevents the accumulation of real estate property by an individual owner; promotes the openness of property relations, as the real owner of the property is identified. In this context, the application of a tax on real estate other than land plots restrains the growth of residential real estate prices and requires harmonization of the legal and institutional framework's fragmentation for social housing taxation. Financial compensation should be provided for construction companies when a developer transfers a certain percentage of the built houses to the social housing fund for internally displaced persons.

\section{CONCLUSION}

The study confirmed that the formation of the affordable housing segment for internally displaced persons directly depends on the choice of priorities when investing in residential real estate. As the current income level of a big part of the population, including internally displaced persons, does not allow them to solve housing problems on their own, the state housing policy should be aimed at minimizing the cost of housing for middle-income citizens from the occupied territories and providing them with preferential mortgages.

From the point of view of endogenous approaches, the correlation, regression, and canonical analysis help define the parameters which directly influence the volumes of commissioned housing. Pearson's methods of correlation analysis and pairwise correlation coefficients revealed and established the level relationships between the volume of housing stock and the population, as well as the number of employed persons; between the volume of housing stock and per capita income, regional domestic per capita product, the volume of investments in housing construction, housing prices; between housing prices and the human development index in the region. Using empirical and economic-statistical methods, it is established that the volume of commissioned housing is particularly affected by the volume of investments in housing construction per capita, per capita income, and actual housing prices, taking into account the level of development of administrative-territorial units. The most significant parameter that affects the volume of housing construction is the amount of investments into per capita housing construction. Also significant, but somewhat less important, are per capita income and actual housing prices taking into account the level of development of administrative-territorial units. 
Regional development programs should take into account social investment priorities relating to the possibility of buy-outs through the mechanism of social housing leasing for internally displaced persons in the absence of other opportunities to own a home; obtaining of a certain percentage of commissioned housing to the social housing fund from developers, providing financial compensations for construction companies; conducting a housing lottery, the proceeds from which will be used to build housing for internally displaced persons.

\section{AUTHOR CONTRIBUTIONS}

Conceptualization: Lyudmyla Alekseyenko, Oksana Tulai.

Data curation: Lyudmyla Alekseyenko, Andriy Kuznietsov, Julia Derkash.

Formal analysis: Lyudmyla Alekseyenko, Oksana Tulai, Andriy Kuznietsov, Julia Derkash.

Methodology: Lyudmyla Alekseyenko, Oksana Tulai, Yuriy Petrushenko.

Project administration: Oksana Tulai, Yuriy Petrushenko.

Validation: Yuriy Petrushenko, Andriy Kuznietsov, Julia Derkash.

Visualization: Lyudmyla Alekseyenko, Oksana Tulai, Andriy Kuznietsov, Julia Derkash.

Writing - original draft: Lyudmyla Alekseyenko, Oksana Tulai, Yuriy Petrushenko, Andriy Kuznietsov. Writing - review \& editing: Lyudmyla Alekseyenko, Yuriy Petrushenko, Julia Derkash.

\section{ACKNOWLEDGMENT}

This research was funded by a grant from the Ministry of Education and Science of Ukraine "Reforming the lifelong learning system in Ukraine for the prevention of the labor emigration: a coopetition model of institutional partnership" (No. 0120U102001).

\section{REFERENCES}

1. Abelson, P. (2009). Affordable Housing: Concepts and Policies. Economic Papers, 28(1), 2738. https://onlinelibrary.wiley. com/doi/pdf/10.1111/j.17593441.2009.00001.x

2. Alekseyenko, L., Tsizhma, O., \& Karpa, I. (2017). Optimization of residential real estate taxation in the context of increasing efficiency of state regulation of social standards. In A. Krysovatyy (Ed.), Modern tendencies of fiscal policy in European economic space: monograph (pp. 249-256). Ternopil: TNEU. Retrieved from http://dspace.wunu. edu.ua/bitstream/316497/30021/1/ Modern\%20tendencies_monografengl\%20\%281\%29.pdf

3. Andrejovska, A., Glova, J., \& Tulai, O. (2020). Investment allocation in Slovakia and Ukraine in terms of effective corporate tax rates. Investment Management and Financial Innovations, 17(3), 332344. http://dx.doi.org/10.21511/ imfi.17(3).2020.25
4. Asaul, A. N., Kazakov, Yu. N., Pasyada N. I., \& Denisova, I. V. (2005). Teoriya i praktika maloetazhnogo zhilishchnogo stroitelstva $v$ Rossii [Theory and practice of low-rise housing in Russia] (563 p.). St. Petersburg: Gumanistika. (In Russian). Retrieved from https://monographies.ru/files/T-7 Teoriya_i_praktika_zhilishchnogo_stroitelstva.pdf

5. Barannik, L. B., \& Sokovets-Makatukha T. V. (2015). Finansove zabezpechennia naselennia dostupnym zhytlom v Ukraini yak neobkhidna umova rozvytku ekonomiky [Financial provision of affordable housing in Ukraine as a necessary condition of economic development]. Naukovi zapysky Natsionalnoho universytetu "Ostrozka akademiya". Seriya "Ekonomika" - Scientific Notes of Ostroh Academy National University, "Economics" Series, 28, 71-79. (In Ukrainian). Retrieved from https://ecj.oa.edu.ua/articles/2015/ n28/16.pdf
6. Bhagat, S. (2017). Mortgage Public Policies and the Financial Crisis. In Financial Crisis, Corporate Governance, and Bank Capital (pp. 12-23). Cambridge: Cambridge University Press. Retrieved from https://www.cambridge.org/core/ books/financial-crisis-corporategovernance-and-bank-capital/ FB9A9BC1D940AD916BDACF5A59C6DC92

7. Binovska, I., Kauškale, L., \& Vanags, J. (2018). The Comparatative Analysis of Real Estate Market Development Tendencies in the Baltic States Baltic Journal of Real Estate Economics and Construction Management, 6, 6-23. https://doi. org/10.1515/bjreecm-2018-0001

8. Cabinet of Ministers of Ukraine. (2019). Postanova "Pro zatverdzhennia Poriadku formuvannia fondiv zhytla dlia tymchasovoho prozhyvannia vnutrishno peremishchenykh osib i Poriadku nadannia $v$ tymchasove korystuvannia zhytlovykh prymishvhen $z$ 
fondiv zhytla dlia tymchasovoho prozhyvannia vnutrishno peremishchenykh osib" [Resolution

"About the statement of the order of formation of funds of housing for temporaryresidence of internally displaced persons and the procedure forproviding temporary assistanceuse of housing from housing funds for temporary residenceinternally displaced persons"]. (In Ukrainian). Retrieved from https://zakon.rada.gov.ua/laws/ show/582-2019-\%D0\%BF

9. Cambridge Dictionary. (2017). Social Housing. Retrieved from http://dictionary.cambridge.org/ dictionary/english/social-housing

10. Cazabat, C., \& Tucci, M. (2019). Unveiling the cost of internal displacement. The ripple effect: economic impacts of internal displacement (37 p.) IDMC. Retrieved from https://www.internal-displacement.org/sites/default/files/ publications/documents/201902economic-impact-cost-estimates. pdf

11. Curto, R., \& Fregonara, E. (2019). Monitoring and Analysis of the Real Estate Market in a Social Perspective: Results from the Turin's (Italy) Experience. Sustainability, 11, 1-22. Retrieved from https:// ideas.repec.org/a/gam/jsusta/ v11y2019i11p3150-d237188.html

12. Diachenko, A. (2018). Napriamy pidvyshvhennia rivnia integratsiinoi spromozhnosti vnutrishno peremishchenykh osib v Ukraini [Directions of increasing the integrated capacity level of internal transfers in Ukraine]. Derzhavne upravlinnia ta mistseve samovriaduvannia - Public Administration and Local Government, 3(38), 6268. (In Ukrainian). Retrieved from http://www.dridu.dp.ua/vidavnictvo/2018/2018_03(38)/10.pdf

13. Ding, D., Huang, X., Jin, T., \& Raphael, L. W. (2017). The Residential Real Estate Market in China: Assessment and Policy Implications. Annals of Economics and Finance, 18(2), 411-442. Retrieved from https://scholar.harvard.edu/ tjin/publications/residential-realestate-market-china-assessmentand-policy-implications
14. Fedoriv, P., \& Lomonosova, N. (2019). Derzhavna zhytlova polityka $v$ Ukraini: suchasnyi stan ta perspektyvy reformuvannia [Public Housing Policy in Ukraine: Current State and Prospects for Reform] (132 p.). Kyiv: CEDOS. (In Ukrainian). Retrieved from https://cedos.org.ua/en/articles/ derzhavna-zhytlova-polityka-vukraini-suchasnyi-stan-ta-perspektyvy-reformuvannia

15. Hansson, A. G., \& Lundgren, B. (2019). Defining Social Housing: A Discussion on the Suitable Criteria. Housing, Theory and Society, 36(2), 149-166. https:// www.tandfonline.com/doi/full/10. 1080/14036096.2018.1459826

16. Harelimana, J. B. (2017). Towards Affordable Low Cost Housing: Strategies of Low Cost Housing Development for the Low Income Population in Rwanda. International Journal of Family Business and Management, 1(1), 1-7. Retrieved from https://symbiosisonlinepublishing.com/familybusiness-management/familybusiness-management09.php

17. Hudz, P. V., \& Sharova, S. V. (2014). Teoriia i praktyka rozvytku rynku nerukhomosti rehionu [Theory and practice of real estate market development in the region] (246 p.). Zaporizhzhia: Akcent Invest-treid. (In Ukrainian). Retrieved from http://eir.zntu.edu. ua/bitstream/123456789/2944/1/ Sharova_The_theory_and_practice.pdf

18. Jacobsen, D. H., Solberg-Johansen, K., \& Haugland, K. (2007). Housing investment and house prices. Economic Bulletin, 1(78), 33-46. Retrieved from https://static.norges-bank.no/contentassets/2f985afb 1b2047c8a82c099d3ac418de/housing_investment_and_house_prices_economic_bulletin_1_2007-2. pdf? $v=03 / 09 / 2017123354 \& f t=. p d f$

19. Kohlscheen, E., Mehrotra, A., \& Mihaljek, D. (2020). Residential Investment and Economic Activity: Evidence from the Past Five Decades. International Journal of Central Banking, 16, 287-329. Retrieved from https://www.ijcb. org/journal/ijcb20q5a7.pdf
20. Kwenda, F. (2015). Investment and financing constraints: can working capital management make a difference in South Africa? Banks and Bank Systems, 10(1), 24-33. Retrieved from https://businessperspectives.org/journals/banksand-bank-systems/issue-185/ investment-and-financingconstraints-can-working-capitalmanagement-make-a-differencein-south-africa

21. Lisi, G. (2019). The search and matching process in the housing market: Explaining the phenomenon of the house price dispersionю. Journal of European Real Estate Research, 12(3), 380-391. https://doi.org/10.1108/ JERER-02-2019-0003

22. Mitra, S., \& Walczak, S. (2012). Consumer decision making forresidential mortgages. In Proceedings of the Annual Hawaii International Conference On System Sciences, Maui, Hawaii USA (pp. 1424-1433). Retrieved from https://www.computer.org/csdl/ pds/api/csdl/proceedings/download-article/12OmNARRYqY/pdf

23. Ogden, C. (2020). Working from home "the future" of social housing sector, report suggests. Retrieved from https://housingexecutive. co.uk/working-from-home-thefuture-of-social-housing-sectorreport-suggests/

24. Rosser, M. E. \& Sanders, D. (2017). A History of Mortgage Banking in the West: Financing America's Dreams (408 p.). University Press of Colorado.

25. Sadoviak, M. S. (2019). Finansuvannia zhytlovoho budivnytstva $v$ Ukraini [Financing of housing construction in Ukraine] (Candidate's thesis). Kyiv: DVNZ "Universytet bankivskoi spravy”. (In Ukrainian). Retrieved from http://ubs.edu.ua/ images/PDF/Vidguk/sadoviak_financing_of_housing_ABS_.pdf

26. Smith, S. J., Munro, M., \& Christie, H. (2006). Performing (Housing) Markets. Urban Studies, 43(1), 81-98. https://doi. org/10.1080/00420980500409276

27. State Fund for Support of Youth Housing Construction. (2020). 
State Social Program: Affordable Housing. Retrieved from https:// www.molod-kredit.gov.ua/en/

28. Tajani, F., \& Morano, P. (2018). An empirical-deductive model for the assessment of the mortgage lending value of properties as securities for credit exposures. Journal of European Real Estate Research, 11(1), 44-70. https://doi. org/10.1108/JERER-01-2017-0007

29. Torluccio, G., \& Dorakh, A. (2011). Housing Affordability and Methodological Principles: An Application. International Research Journal of Finance and Economics,
79, 64-78. Retrieved from https:// www.researchgate.net/publication/286747360_Housing_Affordability_and_Methodological_Principles_An_Application

30. United Nations Commission on Human Rights. The Guiding Principles on Internal Displacement, UN Doc. E/CN.4/1998/53/ Add.2 (1998). Retrieved from https://www.unhcr.org/protection/ idps/43ce1cff2/guiding-principlesinternal-displacement.html

31. Woznyak, H. V. (2019). Suchasni mekhanizmy finansuvannia budivnytstva zhytla v Ukraini: problemy ta shliakhy vyrishennia [Modern Mechanisms for Financing the Housing Construction in Ukraine: Problems and Ways to Solutions]. Biznes Inform - Business Inform, 8, 111-116. (In Ukrainian). Retrieved from http:// www.business-inform.net/article/? year=2019\&abstract=2019_8_0_1 11_1168lang=en

32. Wyatt, P. (2018). Can land value uplift deliver affordable housing? Experiences from England. Journal of European Real Estate Research, 11(1), 87-101. https://doi. org/10.1108/JERER-02-2017-0009 